\title{
Employee Retention Management
}

\author{
Magdalene Peter, S.Fabiyola Kavitha, R. Ramamoorthy
}

\begin{abstract}
The purpose of the proposed look at is to recognize the massive distinction within the opinions amongst personnel working in pharma quarter with reference to worker retention practices on the premise of their designation, qualification, nature of employment, marital repute and profits. Out of 150 employees, 100 personnel were taken because the sample for the existing take a look at from 3 districts of Telangana region (i.e., Nizamabad, Adilabad and Karimnagar). The statistics changed into gathered through a questionnaire and dispensed to the employees to fill their choices in the appropriate columns. The uncooked facts became analysed the usage of SPSS to find out the results in step with the hypotheses formulated. The findings of the study show that there may be no massive difference among scientific Representatives and vicinity income Managers, between graduates and postgraduates, between married and single. however, there may be a large difference between everlasting and settlement personnel operating in pharmaceutical quarter situated within the observe place. No enormous distinction become located amongst special income organizations of personnel also. it's far concluded that the opinion levels of MRs become barely higher than the ASMs. This might be because of the interest and involvement proven via MRs as they're new entrants to the sector.
\end{abstract}

Keywords : Employee Retention, designation, qualification, nature of employment, marital status, and income.

\section{INTRODUCTION}

The term "worker retention" first commenced to seem with regularity at the enterprise scene inside the 1970s and early 'Nineteen Eighties. until then, all through the early and mid-1900s, the essence of the relationship among organisation and worker were (by way of and massive) a announcement of the repute quo: you return work for me, do an excellent activity, and, as long as economic situations permit, i will retain to employ you. [25],[27],[29]It became commonplace for people who entered the activity marketplace as late because the 1950s and Nineteen Sixties to stay with one organization for a totally long term from time to time all through their operating lifestyles. if they modified jobs, it turned into normally a primary profession and life selection, and a person who made many and frequent process adjustments became visible as relatively out of the regular. As a herbal end result of this "status quo" organisation-worker relationship, an worker leaving his or her process voluntarily was visible as an aberration,

Revised Manuscript Received on July 22, 2019.

Magdalene Peter, Department of MBA, Bharath Institute of Higher Education and Research, Tamilnadu, India. Email: magdalene.bsb@ gmail.com Dr.S.Fabiyola Kavitha, Department of MBA, Bharath Institute of Higher Education and Research, Tamilnadu, India. Email: fabiyolakavitha@gmail.com

R.Ramamoorthy, Department of MBA, Bharath Institute of Higher Education and Research, Tamilnadu, India. Email: ramamoorthy0071@gmail.com something that shouldn't without a doubt have happened. in any case, the essence of "reputation quo" is simply that little or not anything ought to exchange within the dating. [1], [ 3],[5]

\section{REVIEW OF LITERATURE}

In step with Get Les Mckeown's employee retention is define as " effective worker retention is a scientific effort by using employers to create and foster an surroundings that encourages modern-day personnel to remain employed by means of having policies and practices in place that address their divers desires. additionally of issue are the expenses of worker turnover (inclusive of hiring costs. productiveness loss). replacement fees usually are 2.five times the salary of the person. [31],[33],[32]The prices associated with turnover may additionally include lost customers, enterprise and damaged morale. similarly there are the hard charges of time spent in screening, verifying credentials, references, interviewing, hiring, and training the new worker just to get again to wherein you commenced.". [2 ],[ 4],[6]

\section{OBJECTIVES OF THE STUDY}

To study employee retention control in wellknown and with special connection with STEPL, Thoothukudi, in particular. To recognize the benefits furnished by way of the management to maintaining their employees. To recognise the facilities furnished via the employer to maintain their personnel. [20],[ 22], [24]To perceive the importance of retention control strategies of the companies. To realize an action plan used by the control to decorate retention inside the organisation. [7], [9], [11]

\section{RESEARCH METHODOLGY}

Research methodology is a way to systematically clear up the studies problem. it could be understand as a technology of studying how research systematically solves the research problem. in this have a look at of the researcher studies numerous steps which can be usually adopted in analyzing this studies trouble in conjunction with the logic being them. it is necessary for the researcher to know not only the research techniques/techniques but also the method. [8],[10] ,[12]

In this method the researcher speak the goal selection of location, pattern layout, information tabulation and analysis tools used to analyzed records duration of the examine and the challenge of study. [13], [15] ,[ 17]

\section{A. SCOPE OF THE STUDY}

The problem of managing for worker retention entails a company's strategic movements to hold personnel motivated and 
centered in order that they decide on to remain employed and absolutely productive for the gain of the company.

A comprehensive worker retention software can play an critical position in each attracting and keeping key personnel, in addition to in decreasing turnover and its related costs. All of these make a contribution to an enterprise's productiveness and typical commercial enterprise overall performance. [14],[16], [18]

\section{V.RESULTS AND DISCUSSION}

TYEAR OF studies - paintings environment - INCENTIVE supplied via THE organization - current job - prompted people - growth AND promoting - career development on the enterprise - corporation WELFARE - enterprise WELFARE - OPINION at the working environment- scientific centers WELCOMES NEW thoughts AND improvements concerning superior SUBORDINATE courting.Complaint managing and thought container can be positioned in the premises to acquire employee grievances and tips.agency must have continuous interaction with all personnel.Agency may take steps to present comments on employee overall performance on a r regular foundation.Reasonable[26],[28],[30] will increase in income should receive with timely progressing would help the enterprise to preserve its personnel.employee may be influenced to welcome the alternate.management ought to deliver extra interest to inspire all employee and that they have to accept worker's new ideas and improvements.

\section{CONCLUSION}

Retention is an vital concept that has been receiving sizeable attention from academicians, researcher and practicing HR supervisor.In its essence retention comprises essential element which include the want or content, search and desire of strategies purpose-directed behaviour, social assessment of rewards reinforcement and overall performance pride. The growing attention paid toward retention is justified due to several motives.encouraged worker comes out with new manner of doing task.they are nice oriented. they are greater effective.Any generation desires motivated employees to adopt it efficaciously. [19],[21],[23]

\section{REFERENCES}

1. G BharthVajan R., Ramachandran S.,Psychographic dimensions of training,2016,International Journal of Pharmacy and Technology,V-8,I-4,P-23727-23729

2. Balakrishnan P., Bharthvajan R.,A study on human resource planning in hospitals in Chennai City,2014,International Journal of Applied Engineering Research,V-9,I-22,P-7503-7507

3. Priyadarsini P., Bharthvajan R.,Role of emotional intelligence training programme in reducing the stress of the nurses, 2014,International Journal of Applied Engineering Research,V-9,I-22,P-7411-7421

4. Kerinab Beenu G., Bharthvajan R.,Empirical analysis on the cosmetic buying behavior of young women in South India,2014,International Journal of Applied Engineering Research,V-9,I-22,P-7361-7366

5. Balakrishnan P., Bharthvajan R.,Whistling in the wind,2014,International Journal of Applied Engineering Research,V-9,I-22,P-7586-7593

6. Krishnan B., Peter M.,Health hazards of Indian Bpo employee-an alarming issue,2014,International Journal of Applied Engineering Research,V-9,I-22,P-7336-7341

7. Kerinab Beenu G.H., Peter M.,Role of insurance in economic development,2014,International Journal of Applied Engineering Research,V-9,I-22,P-7532-7539

8. Balakrishnan P., Peter M., Priyadarsini P.,Efficiency of safety measures for wellbeing of employees in manufacturing industry,2014,International Journal of Applied Engineering Research,V-9,I-22,P-7376-7382

9. Anbarasi M., Praveen Kumar S.,Online sales promotions of herbal products and its effectiveness towards tanisha.com,2019,Indian Journal of Public Health Research and Development,V-10,I-1,P-195-200

10. Anbarasi M., Praveen Kumar S.,Various online marketing and promotions strategies to improve the validation towards the organic products in the pharmaceutical sectors,2019,Indian Journal of Public Health Research and Development,V-10,I-1,P-263-269

11. Loganathan R., Praveen Kumar S.,Grievance handling a key factor for solving issues of employees in an organization,2014,International Journal of Applied Engineering Research,V-9,I-22,P-7483-7491

12. Loganathan R., Praveen Kumar S.,Study on preference of private label brands in super and Hypermarkets, 2014,International Journal of Applied Engineering Research,V-9,I-22,P-7327-7335

13. Smitha M., Praveen Kumar S.,Understanding stress and its managementamong the nurses in Chennai city,2014,International Journal of Applied Engineering Research,V-9,I-22,P-7560-7565

14. Kerinab Beenu G.H., Praveen Kumar S.,A study on the investment behavior of Chennai investors in mutual fund schemes,2014,International Journal of Applied Engineering Research,V-9,I-22,P-7520-7525

15. Loganathan R., Praveen Kumar S.,Retention strategies key for organizational productivity,2014,International Journal of Applied Engineering Research,V-9,I-22,P-7443-7447

16. Pavithra J., Ganesan M., Brindha G.,State wise analysis of microfinance sector in India,2016,International Journal of Pharmacy and Technology,V-8,I-4,P-23417-23432

17. Pavithra J., Ganesan M.,A comparative study on microfinance in India and abroad,2016,International Journal of Applied Business and Economic Research,V-14,I-8,P-5471-5476

18. Pavithra J., Ganesan M.,A study on awareness and impact of micro-financial schemes,2016,International Journal of Applied Business and Economic Research,V-14,I-8,P-5449-5460

19. Senthilmurugan P., Pavithra J.,Consumer preference towards organised retailing with reference to Big Bazaar,2014,International Journal of Applied Engineering Research,V-9,I-22,P-7469-7475

20. Senthilmurugan P., Pavithra J.,Implication of social media marketing in growing healthcare industry,2014,International Journal of Applied Engineering Research,V-9,I-22,P-7448-7456

21. Loganathan R., Pavithra J.,Consumer perception towards private label brand over other brands in super markets and hypermarkets,2014,International Journal of Applied Engineering Research,V-9,I-22,P-7355-7360

22. Kerinab Beenu G., Pavithra J.,Tradeâ€"off between liquidity and profitability in logistics industry,2014,International Journal of Applied Engineering Research,V-9,I-22,P-7398-7401

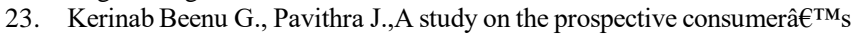
perception towards utility cars in Chennai city,2014,International Journal of Applied Engineering Research,V-9,I-22,P-7526-7531

24. Pavithra J., Dilli Babu P., Ambuli T.V.,A study on budgetary control at Maruti Service Masters, Chennai,2014,International Journal of Applied Business and Economic Research,V-12,I-2,P-151-161

25. Pavithra J., Dilli Babu P., Ambuli T.V.,A study on customer satisfaction of retro Garments Pvt Ltd, Chennai,2014,International Journal of Applied Business and Economic Research,V-12,I-2,P-381-391

26. Kerinab Beenu G.H., Pavithra J., Senthilmurugan P.,A study on the influence of promotional activities for TATA ARIA among consumers in Chennai,2014,International Journal of Applied Engineering Research,V-9,I-22,P-7572-7578

27. Vijayaragavan S.P.,An investigative expert that's general FBG sensors,International Journal of Mechanical Engineering and Technology,V-8,I-8,PP-1500-1505,Y-2017

28. Vijayaragavan S.P.,Equalization routing protocol for $\mathrm{Wi}-\mathrm{Fi}$ sensor strategy,International Journal of Mechanical Engineering and Technology,V-8,I-8,PP-1662-1666,Y-2017

29. Karthik B., Kiran Kumar T.V.U., Vijayaragavan P., Bharath Kumaran E.,Design of a digital PLL using $0.35 \hat{\mathrm{I}}^{1} / 4 \mathrm{~m}$ CMOS technology,Middle East Journal of Scientific Research,V-18,I-12,PP-1803-1806,Y-2013

30. Kanniga E., Selvaramarathnam K., Sundararajan M.,Kandigital bike operating system,Middle - East Journal of Scientific Research,V

31. Jasmin M., Vigneshwaran T., Beulah Hemalatha S.,Design of power aware on chip embedded memory based FSM encoding in FPGA,International Journal of Applied $\quad$ Engineering 
32. Jasmin M.,Optimization techniques for low power VLSI circuits,Middle East Journal of Scientific Research,V-20,I-9,PP-1082-1087,Y-2014

33. Jasmin M., Vigneswaran T.,Fuzzy controller for error control of on - Chip communication,2017 International Conference on Algorithms, Methodology, Models and Applications in Emerging Technologies, ICAMMAET 2017,V-2017-January,I-,PP-1-5,Y-2017

\section{AUTHORS PROFILE}

Magdalene Peter Assistant Professor ,Department of MBA, Bharath Institute of Higher Education and Research, Tamilnadu, India

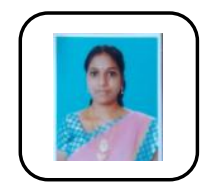

Dr.S.Fabiyola Kavitha Associate Professor ,Department of MBA, Bharath Institute of Higher Education and Research, Tamilnadu, India

R.Ramamoorthy Assistant Professor, Department of MBA, Bharath Institute of Higher Education and Research, Tamilnadu, India 